\title{
TOXOCARIASIS IN CHILDREN ATTENDING A PUBLIC HEALTH SERVICE PNEUMOLOGY UNIT IN PARANÁ STATE, BRAZIL
}

Edson V. GUILHERME(1), Ariella A. MARCHIORO(2), Silvana M. ARAUJO(1), Dina Lúcia Morais FALAVIGNA(3), Carolina ADAMI(4), Gustavo FALAVIGNA-GUILHERME(5), Guita RUBINSKY-ELEFANT(6) \& Ana Lucia FALAVIGNA-GUILHERME(1)

\begin{abstract}
SUMMARY
The enzyme-linked immunosorbent assay (ELISA) is the most widely used tool to detect anti-Toxocara IgG antibodies for both serodiagnostic and seroepidemiological surveys on human toxocariasis. In the last eight years a high prevalence of toxocariasis (32.2$56.0 \%$ ) has been reported in children attending public health units from municipalities in the state of Paraná, Brazil. Therefore, the aim of this work was to compare the frequency found among the general child population with that of children attending a public pneumology service in Maringá, Paraná, Brazil and describe the laboratorial, clinical and epidemiological findings. The research was conducted at the Consórcio Público Intermunicipal de Saúde do Setentrião Paranaense (CISAMUSEP) from July 2009 to July 2010 among children aged between one and 15 years. From a total of 167 children studied, only 4.2\% (7/167) tested positive for anti-Toxocara spp. IgG antibodies and presented mild eosinophilia (2/7), increased serum IgE levels (6/7) and a positive allergy test for mites (5/7). The presence of pets (dogs or cats) at home did not correlate with the seroprevalence. In conclusion, cases of toxocariasis involving the respiratory tract are rare in children attending a public health pneumology unit in the northwestern region of Paraná State, despite the high prevalence of this type of toxocariasis among the infantile population attending Basic Health Units in the same geographical area.
\end{abstract}

KEYWORDS: Toxocara spp.; Children; Respiratory tract; Toxocariasis.

\section{INTRODUCTION}

Human toxocariasis is present worldwide and children are more likely to be exposed to the risk of infection ${ }^{4,16,23}$. Transmission occurs by the accidental ingestion of embryonated eggs of Toxocara canis or T. cati, the roundworms of dogs and cats, respectively, which may be present in soil and contaminated sand ${ }^{16,20,22}$ with the feces of these animals ${ }^{9,13,23,24}$. The migration of Toxocara infective larvae through human tissues does not result in severe clinical manifestations in most cases ${ }^{18,20,22}$. However, it may cause fever, hepatomegaly, splenomegaly, respiratory symptoms, muscle pain, ocular damage and eosinophilia, and circulating antiToxocara $\mathrm{IgG}$ antibodies are often present ${ }^{2,11,20}$.

Human toxocariasis is currently classified into four clinical forms: systemic or visceral larva migrans (VLM), compartmentalized (neurologic and ocular toxocariasis), cover, and asymptomatic ${ }^{16,22}$. In the systemic form, pulmonary involvement is shown through asthmatic episodes and/ or acute bronchitis and eosinophilia ${ }^{12,18,20}$. These symptoms are due to an increase in inflammatory cells (macrophages and eosinophils) and a change in the host lymphocyte subpopulation in response to antigens secreted by the migrating larvae of T. canis $^{12,25}$.
The method of choice for both immunodiagnostic and epidemiological studies is the enzyme-linked immunosorbent assay (ELISA) test using the excretory-secretory antigens of infective larvae of $T$. canis (TES), which possess high sensitivity and specificity ${ }^{6,20,25}$. Many studies concerning the seroprevalence of toxocariasis in children have been conducted in Brazil reporting 12.1-60.0\% in the northeast $\mathrm{t}^{9,22,26}, 3.0-35.5 \%$ in the midwest $\mathrm{t}^{9,22}$, $21.5-52.0 \%$ in the north ${ }^{9,22}$ and $2.8-54.8 \%$ in the southeast ${ }^{9,22,25}$.

Since 2003, our group has been conducting research to evaluate the prevalence of toxocariasis in children from one to 15 years of age attending public basic health units (BHU) in northwestern Paraná. In the nine cities investigated (Astorga, Colorado, Mandaguaçu, Mandaguari, Marialva, Maringá, Nova Esperança, Paiçandu, and Sarandi), we have observed that the seroprevalence of toxocariasis varies from $32.2 \%$ to $56 \%, 1,14,15,17,18$. Among the signs and symptoms analyzed, pulmonary ones were the most reported ${ }^{1,5,14,15,17,18}$. Therefore, the aims of this work were to verify whether the rates of toxocariasis frequency found in our previous research was repeated in children referred to the public pneumology service, and describe the laboratorial, clinical and epidemiological findings of the seropositive children.

(1) Programa de Pós-graduação em Ciências da Saúde, UEM, Maringá, PR, Brazil

(2) Departamento de Farmácia, Faculdade Ingá, Uningá, Maringá, PR, Brazil.

(3) Departamento de Ciências Básicas da Saúde, Universidade Estadual de Maringá, UEM, Maringá, PR, Brazil.

(4) Departamento de Farmácia, Universidade Estadual de Maringá, UEM, Maringá, PR, Brazil.

(5) Departamento de Medicina, Pontifícia Universidade Católica do Paraná, Curitiba, PR, Brazi

(6) Laboratório de Soroepidemiologia e Imunobiologia, Instituto de Medicina Tropical de São Paulo, São Paulo, SP, Brazil.

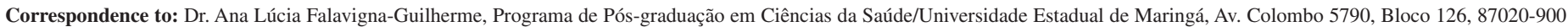

Maringá, Paraná, Brasil. Tel.: +55.44.3011-8987, Fax: +55.44.3011-4860. E-mail: alfguilherme@uem.br 
GUILHERME, E.V.; MARCHIORO, A.A.; ARAUJO, S.M.; FALAVIGNA, D.L.M.; ADAMI, C.; FALAVIGNA-GUILHERME, G.; RUBINSKY-ELEFANT, G. \& FALAVIGNA-GUILHERME, A.L. - Toxocariasis in children attending a Public Health Service Pneumology Unit in Paraná State, Brazil. Rev. Inst. Med. Trop. Sao Paulo, 55(3): 189-92, 2013.

\section{MATERIALS AND METHODS}

Sampling: The study included 167 children aged from one to 15 years attending the Pneumology Unit of the public health service (Consórcio Público Intermunicipal de Saúde do Setentrião Paranaense - CISAMUSEP) which is located in Maringá and is the referral service for the northwest of Paraná, Brazil, from July 2009 to July 2010. The CISAMUSEP receives children referred by BHUs and other health services in 30 cities. The results were compared with the epidemiological data of children from the same region using previous reported studies ${ }^{1,5,14,15,17,18}$.

Laboratory methods: Blood samples from the children in the study sample were collected at the Laboratory of Parasitology, Universidade Estadual de Maringá (UEM), and the serum was stored at $-20{ }^{\circ} \mathrm{C}$ until use. Anti-Toxocara spp. IgG antibodies were detected by means of an ELISA test using TES antigens, which were obtained according to the method of DE SAVIGNY et al. (1979) ${ }^{6}$, modified by ELEFANT et al. $(2001)^{7}$. All sera were previously absorbed with Ascaris suum antigens ${ }^{7}$. The cut-off value was calculated based on the mean optical density (OD) of 96 negative control sera plus three standard deviations. The results were expressed as the reactivity index (RI), which was calculated by the ratio between the OD of the sample and the OD of the cut-off value. Samples with an RI $\geq 1$ were considered reactive. All samples were tested in duplicate. Positive and negative control sera, as well as a threshold control serum (TCS), were used in all runs. The TCS was prepared with a pool of reactive samples diluted in a volume of pooled negative samples to provide an OD equal to the cut-off. All samples were tested in duplicate.

Complete blood counts (CBC) and eosinophilia were compiled. Eosinophilia was considered when the number of eosinophils was $\geq 500$ cells/ $\mu \mathrm{L}$ and classified as: normal $(<6 \%)$, mild (6-10\%), moderate $(11-15 \%)$ and severe $(>15 \%)$ eosinophilia ${ }^{21}$.

IgE total levels were measured by nephelometry according to the manufacturer's recommendations (NIGE Siemens ${ }^{\circledR}$ ). The IgE reference values were: $<1.5 \mathrm{IU} / \mathrm{mL}$ for newborns; $<15 \mathrm{IU} / \mathrm{mL}$ for children up to one year old; $<60 \mathrm{IU} / \mathrm{mL}$ for children aged from one to five years old; $<90 \mathrm{IU} / \mathrm{mL}$ for children from six to nine years old and $<200 \mathrm{IU} / \mathrm{mL}$ for children from 10 to 15 years old.

Skin-prick tests: Hypersensitivity allergy tests were performed by skin-prick tests with commercial extracts (Prick Test ${ }^{\circledR}$, FDA-Allergenic), according to the manufacturer's instructions. The allergens, tested on the right forearm, were grass pollen, feathers, fungi, house dust, Dermatophagoides pteronyssinus, Dermatophagoides farinae, Blomia tropicalis, dog hair, cat dander, cockroach, sheep's wool, Aspergillus sp., Penicillium sp., and pollen (grass extract).

Clinical and epidemiological data: The following data were recorded for each patient: reasons for referral to a Pneumology Unit, signs and symptoms observed by the physician at the time of the examination (rhinitis, bronchitis, asthma, fever, pneumonia, colds or cough), and presence of pets - dogs or cats - at home.

Chest X-rays were performed at baseline and at follow-up when necessary. Treatment with albendazole $(10 \mathrm{mg} / \mathrm{kg} \text { per day })^{13}$ for 10 consecutive days was prescribed when both clinical and laboratory evidence for toxocariasis was found.

This study was approved by the UEM Ethics Committee of Research Involving Human Beings (COPEP/UEM-018/2008) and by the CISAMUSEP.

\section{RESULTS}

Previous seroepidemiological studies involving children attending regional BHUs in the Brazilian state of Paraná have reported seropositivity rates between $32.2 \%$ and $56.0 \%{ }^{1,5,14,15,17,18}$. However, in our study, only seven out of 167 children (4.2\%) showed anti-Toxocara spp. IgG antibodies; two of them (1.2\%) had moderate eosinophilia and six showed high IgE levels (Table 1).

The chest X-rays were normal, except one child (case *2) who showed an increased bronchial plot (Table 1). Five of the seven children showed positive reactions to the allergens tested, mostly for mites. In relation to the clinical signs observed, shortness of breath was the main reason for attending the BHU.

Clinical signs of bronchitis and eosinophilia were present in one patient (case $* 4$ ), which disappeared after being treated with albendazole. Despite having several domestic animals at home, this patient did not show an atopic response to the tested allergens (Table 1 ). Cases $* 2, * 6$ and $* 7$ improved after albendazole treatment, whilst case $* 5$ had no response upon the same treatment. Cases $* 1$ and $* 3$ did not receive specific treatment for toxocariasis because the patients did not return to the public pneumology service after the conclusion of the exams.

\section{DISCUSSION}

In contrast to the large number of children presenting seropositivity for Toxocara spp. in the area, few cases of toxocariasis were identified in this study among those with pulmonary involvement. Exposure to Toxocara spp. in childhood is a very common condition in our region ${ }^{1,5,15,17}$ and it is expected that this could result in an increased demand for specialized pulmonary disease services. Nevertheless, this is not the case. Children with minor respiratory involvement are treated by primary care physicians in the BHUs.

Previous studies in this region have reported that eosinophilia is present in $7.8 \%(30 / 386)^{1,5,14,15,17,18}$. In this study, we have observed two cases of moderate eosinophilia in patients with anti-Toxocara spp. IgG antibodies. Peripheral eosinophilia is not always specific to toxocariasis, but it has been frequently associated to human toxocariasis, especially in young children who seem to have a more symptomatic course of the disease ${ }^{16,21}$. The increase of IL5, resulting from a dominant type of Th2 response, leads to eosinophilia in Toxocara infections ${ }^{20,22}$. PALUDO et $a l .{ }^{17}$ suggested that eosinophilic patients may be associated with toxocariasis 149 times more than seronegative patients. PINELLI and ARAZEMENDI ${ }^{20}$ also established that blood eosinophils were significantly higher in the Toxocara-seropositive than in the seronegative group. Thus, serodiagnostic tests for toxocariasis should be included in the differential diagnosis of eosinophilia, especially in children and in adults with mild eosinophilia ${ }^{10,11,21}$.

Respiratory symptoms as well as increased $\operatorname{IgE}$ levels have been 
GUILHERME, E.V.; MARCHIORO, A.A.; ARAUJO, S.M.; FALAVIGNA, D.L.M.; ADAMI, C.; FALAVIGNA-GUILHERME, G.; RUBINSKY-ELEFANT, G. \& FALAVIGNA-GUILHERME, A.L. - Toxocariasis in children attending a Public Health Service Pneumology Unit in Paraná State, Brazil. Rev. Inst. Med. Trop. Sao Paulo, 55(3): 189-92, 2013.

Table 1

Clinical, laboratory and epidemiological data for children who presented with anti-Toxocara spp. IgG antibodies at the "Consórcio Público Intermunicipal de Saúde do Setentrião Paranaense" (CISAMUSEP), Maringá, Paraná State, Brazil

\begin{tabular}{|c|c|c|c|c|c|c|c|c|c|}
\hline \multirow[b]{2}{*}{ Case } & \multirow[b]{2}{*}{ Age } & \multicolumn{5}{|c|}{ Results of laboratory tests } & \multirow{2}{*}{$\begin{array}{l}\text { Reason for } \\
\text { consultation }\end{array}$} & \multirow{2}{*}{$\begin{array}{l}\text { Rhinitis, } \\
\text { asthma or } \\
\text { bronchitis }\end{array}$} & \multirow{2}{*}{$\begin{array}{c}\text { Number of } \\
\text { dogs and cats } \\
\text { in the house- } \\
\text { hold }\end{array}$} \\
\hline & & $\operatorname{IgE}$ & $\begin{array}{c}\text { Eosinophilia } \\
\left(\text { cells } / \mathrm{mm}^{3}\right)\end{array}$ & $\begin{array}{c}\text { Degree of } \\
\text { eosinophilia }\end{array}$ & Radiograph & $\begin{array}{l}\text { Prick test } \\
\text { positive }^{\mathrm{c}}\end{array}$ & & & \\
\hline 1 & 3 & 258.1 & 60 & Normal & Normal & No & Breathlessness & Yes & 1 \\
\hline 2 & 6 & 628.2 & 332 & Normal & $\begin{array}{c}\text { Increased } \\
\text { bronchial plot }\end{array}$ & Yes & $\begin{array}{l}\text { Recurrent } \\
\text { respiratory } \\
\text { infection }\end{array}$ & Yes & 0 \\
\hline 3 & 6 & $92.6^{\mathrm{a}}$ & 213 & Normal & Normal & Yes & Breathlessness & Yes & 1 \\
\hline 4 & 8 & 361.6 & $676^{\mathrm{b}}$ & Moderate & Normal & No & Breathlessness & Yes & 18 \\
\hline 5 & 9 & 437.9 & $568^{\mathrm{b}}$ & Moderate & Normal & Yes & $\begin{array}{l}\text { Allergic } \\
\text { asthma }\end{array}$ & Yes & 2 \\
\hline 6 & 4 & $>1100$ & 159 & Normal & Normal & Yes & $\begin{array}{l}\text { Allergic } \\
\text { asthma }\end{array}$ & Yes & 0 \\
\hline 7 & 3 & 1003 & 452 & Normal & Normal & Yes & Breathlessness & Yes & 1 \\
\hline
\end{tabular}



reported in toxocariasis by many authors ${ }^{3,8,25}$. In this study six patients had increased levels of $\mathrm{IgE}$, and in five out of seven cases breathlessness was reported as the main complaint. SHAZLY et al. ${ }^{24}$ observed that patients with bronchial asthma have a high probability of developing clinical symptoms after an infection with Toxocara spp. COLLI et al. ${ }^{5}$ observed similar results in children attending BHUs in three municipalities in this region, with $1.9 \%$ of children presenting high rates of eosinophilia, shortness of breath and increased levels of anti-Toxocara spp. IgG. MARCHIORO et $a l .{ }^{14}$ reported that young patients with asthma and pulmonary involvement may also have hepatomegaly, eosinophilia and increased levels of IgE. Recently, LOPEZ et al. ${ }^{12}$ and PINELLI \& ARANZAMENDI ${ }^{20}$ discovered that infection with Toxocara spp. leads to an exacerbation of experimental allergic airway inflammation, since infections with this helminth share common clinical features with allergic asthma such as wheezing, coughs, mucus hyper-secretion and bronchial hyper-reactivity. Likewise, infection with Toxocara spp. results in the induction of a dominant T-helper 2 (Th2) type of immune response characterized by the production of cytokines such as Interleukin-4 (IL4), IL-13 and IL-5, which causes eosinophilia and increased levels of IgE, respectively ${ }^{3,20}$. Larval invasion of, and migration through the lungs might be the cause of wheezing and other asthma-like symptoms ${ }^{25}$, but the question of whether Toxocara antigens could trigger allergic asthma in Toxocara infected individuals is still being evaluated ${ }^{12,20}$.

Most patients who were seropositive for Toxocara spp. also had increased IgE levels and skin allergenic reactivity associated mainly with clinical manifestations and inhalant aeroallergens ${ }^{11}$. However, BUIJS et al. ${ }^{3}$ explains that Toxocara spp. may stimulate allergic asthma and atopic manifestations due to a hereditary mechanism that distorts type 2 T-helper cell function, promoting parasite host longevity through the increase of an allergen-specific and Toxocara-specific IgE. Mice infected with Toxocara spp. showed serious respiratory allergic inflammation leading to eosinophilia and respiratory tract hyper reactivity ${ }^{19}$. Some of the symptoms typical to VLM such as bronchial spasms, pneumonia and cutaneous reactions ${ }^{25}$ were not observed in our study.

The decrease in the severity of the clinical signs and symptoms has been used in all of the published trials to estimate the end-point of parasitism in VLM patients ${ }^{22}$. In our study, the treatment with albendazole has been evaluated as effective in four out of five children treated, including those who had had contact with dogs and cats. In fact, the prevalence of this zoonosis can be attributed to cultural practices regarding domestic animals $5,20,22,27$.

The seroprevalence of Toxocara infection was low among children attending a public Pneumonology Unit located in the northwestern region of Paraná. However, pulmonary disease specialists and pediatricians should be aware of the high prevalence of toxocariasis in the general pediatric population in this area.

\section{RESUMO}

\section{Toxocaríase em crianças atendidas em Unidade de Pneumologia do Serviço de Saúde Pública, Paraná, Brasil}

O teste imunoenzimático (ELISA) constitui a ferramenta mais utilizada no diagnóstico individual da toxocaríase humana e/ou em inquéritos soroepidemiológicos para pesquisa de anticorpos IgG antiToxocara spp. Tendo em vista a elevada freqüência da toxocaríase (32,2\% e 56,0\%) observada em crianças atendidas em Unidades Básicas de Saúde de municípios do noroeste do Paraná, durante pesquisas realizadas ao longo dos últimos oito anos, o objetivo deste trabalho foi comparar estas frequências em crianças encaminhadas a uma unidade de Pneumologia do serviço de saúde pública da cidade de Maringá, noroeste do Estado do Paraná, Brasil e descrever os achados laboratoriais, clínicos e epidemiológicos das crianças soropositivas. A pesquisa foi realizada no Centro de Especialidades Regional - CISAMUSEP - entre julho de 2009 a julho de 2010, em crianças com idade entre um e 15 anos. De 167 crianças 
GUILHERME, E.V.; MARCHIORO, A.A.; ARAUJO, S.M.; FALAVIGNA, D.L.M.; ADAMI, C.; FALAVIGNA-GUILHERME, G.; RUBINSKY-ELEFANT, G. \& FALAVIGNA-GUILHERME, A.L. - Toxocariasis in children attending a Public Health Service Pneumology Unit in Paraná State, Brazil. Rev. Inst. Med. Trop. Sao Paulo, 55(3): 189-92, 2013.

investigadas, sete $(4,2 \%)$ apresentaram anticorpos IgG anti-Toxocara spp. Entre elas, duas $(1,2 \%)$ crianças soropositivas apresentaram eosinofilia (baixos níveis), seis mostraram níveis elevados de IgE e cinco, teste alérgico positivo, principalmente para ácaros. Concluindo, no noroeste do estado do Paraná foram observados raros casos de crianças com toxocaríase envolvendo o trato respiratório e que foram atendidas por serviços públicos de Pneumologia ainda que na região estudada tenha sido observada elevada prevalência de toxocaríase em crianças assistidas pelas Unidades Básicas de Saúde (BHU).

\section{ACKNOWLEDGMENTS}

We are grateful to all the children who participated in this study. Funding was received from Fundação Araucária, state of Paraná, Brazil.

\section{REFERENCES}

1. Adami CM, Marchioro AA, Melo GC, Falavigna-Guilherme AL. Soroprevalência para toxocaríase em crianças do município de Sarandi, Paraná, Brasil. In: XVIII Encontro Anual de Iniciação Cientifica (EAIC). Londrina; 2009.

2. Anaruma Filho F, Chieffi PP, Correa CRS, Camargo ED, Silveira EPR, Aranha JJB, et al. Human toxocariasis: a seroepidemiological survey in the municipality of Campinas (SP), Brazil. Rev Inst Med Trop Sao Paulo. 2002;44:303-7.

3. Buijs J, Borsboom G, Renting M, Hilgersom WJA, van Wieringen JC, Jansen G, et al. Relationship between allergic manifestations and Toxocara seropositivity: a crosssectional study among elementary school children. Eur Respir J. 1997;10:1467-75.

4. Carvalho EA, Rocha RL. Toxocariasis: visceral larva migrans in children. J Pediatr (Rio J). 2011;87:100-10

5. Colli CM, Rubinsky-Elefant G, Paludo, ML, Falavigna DLM, Guilherme EV, Mattia S, et al. Serological, clinical and epidemiological evaluation of toxocariasis in urban areas of south Brazil. Rev Inst Med Trop Sao Paulo. 2010;52:69-74.

6. De Savigny DH, Voller A, Woodruff AW. Toxocariasis: serological diagnosis by enzyme immunoassay. J Clin Pathol. 1979;32:284-8.

7. Elefant GR, Jacob CMA, Kanashiro EHY, Peres BA. Toxocaríase. In: Ferreira AW, Ávila SLM, editors. Diagnóstico laboratorial das principais doenças infecciosas e auto-imunes. 2. ed. Rio de Janeiro: Guanabara Koogan; 2001. p. 323-32

8. Fernando D, Wickramasinghe P, Kapilananda G, Dewasurendra RL, Amarasooriya M, Dayaratne A. Toxocara seropositivity in Sri Lankan children with asthma. Pediatr Int. 2009;51:241-5.

9. Fragoso RP, Monteiro MBM, Lemos EM, Pereira FEL. Anti-Toxocara antibodies detected in children attending elementary school in Vitoria, State of Espírito Santo, Brazil: prevalence and associated factors. Rev Soc Bras Med Trop. 2011;44:461-6.

10. Karadam SY, Ertug S, Ertabaklar H, Okyay P. The comparison of IgG antibodies specific to Toxocara spp. among eosinophilic and non-eosinophilic groups. New Microbiol. 2008;31:113-6

11. Kwon NH, Oh MJ, Lee SP, Lee BJ, Choi DC. The prevalence and diagnostic value of toxocariasis in unknown eosinophilia. Ann Hematol. 2006;85:233-8.

12. López ML, Bojanich MV, Jacobacci JM, Sercic C, Michelini A, Alonso JM. Toxocara canis y asma bronquial. Medicina (B Aires). 2010;70:75-8.
13. Magnaval JF, Glickman LT. Management and treatment options for human toxocariasis. In: Holland CV, Smith HV, editors. Toxocara the enigmatic parasite. Wallingford: CABI Publishing; 2006. p. 113-26.

14. Marchioro AA, Colli CM, Mattia S, Paludo ML, Melo GC, Adami C, et al. Eosinophilic count and seropositivity for IgG antibodies to Toxocara spp. in children assisted at the public health Service. Rev Paul Pediatr. 2011;29:80-4.

15. Mattia S, Colli CM, Adami CM, Guilherme GF, Nishi L, Rubinsky-Elefant G, et al. Seroprevalence of Toxocara infection in children and environmental contamination of urban areas in Parana State, Brazil. J Helminthol. 2012;86:440-5.

16. Mazur-Melewska K, Mania A, Figlerowicz M, Kemnitz P, Służewski W, Michalak M. The influence of age on a clinical presentation of Toxocara spp. infection in children. Ann Agric Environ Med. 2012;19:233-6

17. Paludo ML, Falavigna DLM, Elefant GR, Gomes ML, Baggio MLM, Amadei LB, et al. Frequency of Toxocara infection in children attended by the health public service of Maringá, south Brazil. Rev Inst Med Trop Sao Paulo. 2007;49:343-8.

18. Pereira C, Marchioro AA, Adami C, Falavigna-Guilherme AL. Soroprevalência para toxocaríase em crianças na cidade de Santa Fé, Paraná, Brasil. In: I Congresso Sul Americano de Farmácia (Consulfarm). Maringá; 2010.

19. Pinelli E, Brandes S, Dormans J, Gremmer E, van Loveren H. Infection with the roundworm Toxocara canis leads to exacerbation of experimental allergic airway inflammation. Clin Exp Allergy. 2008;38:649-58.

20. Pinelli E, Aranzamendi C. Toxocara infection and its association with allergic manifestations. Endocr Metab Immune Disord Drug Targets. 2012;12:33-44.

21. Roldán WH, Espinoza YA, Atúncar A, Ortega E, Martinez A, Saravia M. Frequency of eosinophilia and risk factors and their association with Toxocara infection in schoolchildren during a health survey in the north of Lima, Peru. Rev Inst Med Trop Sao Paulo. 2008;50:273-8.

22. Rubinsky-Elefant G, Hirata CE, Yamamoto JH, Ferreira MU. Human toxocariasis: diagnosis, worldwide seroprevalences and clinical expression of the systemic and ocular forms. Ann Trop Med Parasitol. 2010;104:3-23

23. Santarém VA, Leli FN, Rubinsky-Elefant G, Giuffrida R. Protective and risk factors for toxocariasis in children from two different social classes of Brazil. Rev Inst Med Trop Sao Paulo. 2011;53:66-72.

24. Shazly AM, Abdel Baset SM, Kamal A, Mohammed KA, Sakrs TI, et al. Seroprevalence of human toxocariasis (visceral larva migrans). J Egypt Soc Parasitol. 2009;39:731-44.

25. Smith H, Holland C, Taylor M, Magnaval JF, Schantz P, Maizels R. How common is human toxocariasis? Towards standardizing our knowledge. Trends Parasitol. 2009;25:182-8.

26. Souza RF, Dattoli VCC, Mendonça LR, Jesus JR, Baqueiro T, Santana CC, et al. Prevalência e fatores de risco da infecção humana por Toxocara canis em Salvador, Estado da Bahia. Rev Soc Bras Med Trop. 2011;44:516-9.

27. Tiyo R, Guedes TA, Falavigna DLM, Falavigna-Guilherme AL. Seasonal contamination of public squares and lawns by parasites with zoonotic potential in southern Brazil. J Helminthol. 2008;82:1-6.

Received: 29 March 2012

Accepted: 26 November 2012 